\title{
A Framework of Building and Locational Characteristics Ranking for Purpose-built Offices in Malaysia
}

\author{
${ }^{1}$ Edie Ezwan Mohd Safian*, Abdul Hadi Nawawi ${ }^{2}$ \\ ${ }^{1}$ Universiti Tun Hussein Onn Malaysia Batu Pahat, Malaysia \\ 2Universiti Teknologi MARA (UiTM), Selangor, Malaysia \\ *edie@uthm.edu.my
}

\begin{abstract}
The development of purpose-built office market in Malaysia is primarily resolved by a supplydemand market. Since the office market in Malaysia has displayed significance improvement due to increasing level of competitiveness, many characteristics of purpose-built office have appeared and become prominent during the process of assessment. These characteristics were generally used as indicators in property valuation, building performance as well as office market appraisal. Based on these characteristics, property market participants can evaluate their property proficiently based on their requirements, especially in decision making during business planning, investment or property management. Technology growth and national policy also gave contribution factors on revealing newly characteristics of purpose-built office such as green building, intelligent building and sustainable development model. The purpose of this article is to identify suitable characteristics of purpose-built office that can be used in Malaysia. Integral to achieving this objective, exploration on purpose built office characteristics in a global and local context will be reconsidered. As a result, a building and locational framework of purpose-built office's characteristics in Malaysia will be diagnosed and verified appropriately.
\end{abstract}

Keywords: Purpose-built office, building, locational, characteristics, framework

\section{Introduction}

Purpose-built office (PBO) market in Malaysia had shown a positive development since 1990s. Based on the National Property Information Centre (NAPIC) report, the stability of the economic condition has a significant influence on the PBO market (NAPIC, 1994). During the rapid economic growth, Malaysia had enjoyed an increasing demand for PBO contributed by strong economic market, and there has been a steady increase in development projects conducted by public and private sectors (Rahim \& Co., 2009). Due to its growth, PBO had shown to play a vital role in contributing to the property investment portfolio in the Malaysia office property market. Therefore, office property market had become increasingly competitive. Many buildings and locational characteristics have been revealed in order to meet the needs of property market participants and equilibrium of demand-supply in the office property market. Basically, building and locational characteristics are essential to determine building performance such as grading, classification, green building and sustainable development model. However, these characteristics that have been applied on PBO are different based on it's purpose (Safian, 2010). For example, green technology had been focused on energy saving while innovation was a main characteristic for sustainable development. In addition, building and locational characteristics also have been used to determine office property value, price as well as rental. Government and private sectors also play a vital role to reveal the new characteristics of PBO in order to make the office property market competitive and attractive. Therefore, this paper aims to determine the building and locational characteristics, specifically on PBO and review the related current issues in the country.

\section{Differences of an Office Building and a Purpose-built Office}

An office building consists of a commercial building that has a main lounge that is specially designed for the office's use (Bird, 1996). The objective of developing an office building is to make way for work spaces and a working environment for administration work, business and also management. The office space is usually furnished with office equipment, for example, chairs, desks, computers, and other office equipment that are 
needed for activities in the office space. Nowadays, an office space is furnished with sophisticated communication facilities to enable global connections in order to make sure the business activity and administration run smoothly and effectively such as telephone, fax and high-speed internet broadband. An office building is usually divided to several divisions and occupied by different companies. It also may cover one company in a building based on their business activity, and administration that ran by the company. Normally, a company's office will include a lobby to greet guests, a few meeting rooms, an open office space, the manager's room, and toilets (Bird, 1996). Some office spaces may also have a pantry or a room to prepare food and drinks, as well as a room to rest or prayer room (Safian, 2010). As such, employees are free to arrange their personal activities during break hours. Meanwhile, a PBO represent an office building that has a main function which is for office use, and is supported by other services. The main function when combining the initial design is to optimize the space for its benefit. When about $75 \%$ of the initial design is made for office use, the initial function is changed for a new function (NAPIC, 2007). For example, a PBO is a building which has a main area that functions for office use and supported by other facilities or services, such as bank, post office, restaurants, shopping complexes, and retails (Safian et al., 2011). Basically, the term purpose-built office is typically used by few countries such as United Kingdom, Australia, as well as Malaysia. This intent to differentiate PBO with other commercial buildings or retail offices. In contrast, United States and Russia still use conventional term for office building, which is an 'office building' or 'office block'. However, it depends on the PBO or office building itself whereby it has support services or not.

\section{The Building and Locational Characteristics of Purpose-built Office}

Based on the statement by (Duntavs, 2006), a PBO offers a flexible work environment for growing companies. Moreover, he also stated that the PBO space offered a great investment due to various facilities. Therefore, explanation on the functions of PBO leads to reveal the building and locational characteristics on the PBO itself. This concept is particularly crucial to understand as well as differentiate PBO characteristics with other commercial building characteristics. The building and locational characteristics of PBO, including internal and external characteristics can show the identity of PBO itself as a commercial building which is specifically for office use. However, each PBO has its own building and locational characteristics depending on its location, design, age, services as well as the technology that applied in the building. The uniqueness of building and locational characteristics of PBO can attract investors such as buyers or tenants to invest in PBO. As a result, the building and locational characteristics of PBO have been taken as criteria in determining the performance of PBO by valuer or assessor in a relevance area. These characteristics of PBO can be found in the framework that is based on the building performance indicators such as a green building index, grading, classification, as well as sustainable development model. Even though there were many characteristics introduced by the government or private sectors, the selection of the reliable characteristics is extremely complicated.

Every building and locational characteristics of $\mathrm{PBO}$ are needed to be adapt with local culture, environment as well as suitable in a related area. Based on National Institute of Building Sciences (NIBS), there are two basic characteristics of the office building. Firstly, the space attributes which are requiring flexibility, comfort and safety, energy efficiency, cost-effective and good working environment. Secondly, the building attributes namely safety, healthy, comfortable, durable, and accessible (NIBS, 2009). These characteristics also have been applied by other countries such as United Kingdom and Australia, but they have modified it and focused more details on a certain aspect. Furthermore, the building and locational characteristics also have been used to determine the quality level of PBO. With the selection characteristics, the quality level of PBO is ease to identify in order to categorize the building. With these characteristics, property market participants are free to decide their investment or business activities on the PBO efficiently. Indirectly, with a clear concept and understanding on the building and locational characteristics of PBO, it will be significance to the office property market growth. In a global context, the building and locational characteristics of $\mathrm{PBO}$ have been investigated through advanced studies. As a result, they can easily develop many indicators for quality level, green building index, sustainable development, and classification as done by Colliers-United States, BOMA, HK-Beam, PCA, NIBS and BREEAM. However in Malaysia, the PBO building and locational characteristics studies is still lacking in terms of having a complete and suitable framework that can use and apply accordance to all PBO in the country. The reliable framework of building and locational characteristics for $\mathrm{PBO}$ is still in development. 


\section{Development of a Framework for Building and Locational Characteristics Ranking for Purpose-built Office in Malaysia}

In Malaysia, only few studies have been done by the researcher to look into the building and locational characteristics of $\mathrm{PBO}$ in the country. However, it shows a positive development whereby Green Building Index Malaysia (GBIM) was officially launched in May 2009 (Rahardjati et. al, 2010). The characteristics of PBO have been selected and come out with a structured framework to evaluate building performance in terms of green building. Furthermore, research on the classification model also helps to identify the building and locational characteristics of PBO in more details frameworks as done by (Rahim \& Co., 2009; Safian, 2010; Adnan and Daud, 2008; Darus et al., 2009). Many new characteristics in the classification model have been revealed during these studies. However, the actual framework on the classification is still in development. The building and locational characteristics of PBO at the same time are not meeting the needs of property market participants such as investors, tenants and owners.

Through the study done by (Safian, 2010), the main characteristic of PBO in Malaysia is the presentation, but after the survey had been conducted, number of parking was the main interest by respondents. The same situation also happened on Green Building Index Malaysia (GBIM), which is an indoor environment was the main characteristic that chosen by respondents instead of energy efficiency (Rahardjati et al., 2010). Through that survey as well, innovation is the lower choice by respondents. The results show the building and locational characteristics of PBO in Malaysia are still not satisfying the needs of property market participants, and further study should be done. This paper, however, has identified the building and locational characteristics in a local context that have been used covering all the research relates. This building and locational characteristics have been divided into eight groups namely presentation, management, functionality, services, access and circulation, amenities, green building and sustainable development and location. Table 1, shows a propose framework of building and locational of PBO that will be used to evaluate building performance, which are cover in grading/classification, green building/green technology, and sustainable development.

Table 1: Building and Locational Characteristics of PBO Ranking Framework

\begin{tabular}{|c|c|c|}
\hline Characteristics & Ranking & Explanation \\
\hline \multicolumn{3}{|l|}{ Presentation } \\
\hline \multirow[t]{4}{*}{ External design } & 3 & $\begin{array}{l}\text { Well-designed buildings which use high-quality materials, including brick, painted } \\
\text { stucco and architectural precast concrete or natural stone. Buildings always oriented } \\
\text { towards the main street with entrances and/or windows facing the street. Buildings } \\
\text { are encouraged to have consistent window expressions visible to the street. }\end{array}$ \\
\hline & 2 & $\begin{array}{l}\text { Buildings which use quality materials, including brick, architectural precast concrete } \\
\text { or natural stone. Buildings always oriented towards the main street with entrances } \\
\text { and/or windows facing the street. }\end{array}$ \\
\hline & 1 & $\begin{array}{l}\text { Buildings which use quality materials such as brick. Buildings oriented towards the } \\
\text { secondary street with entrances and/or windows facing the street. }\end{array}$ \\
\hline & 0 & $\begin{array}{l}\text { Buildings which use quality materials such as brick. Buildings oriented towards the } \\
\text { secondary street. }\end{array}$ \\
\hline \multirow[t]{5}{*}{ Finishing } & 3 & $\begin{array}{l}\text { Carpet for Raised Access Floor: Carpet tiles are use on raised access floor. Both } \\
\text { carpets attached to floor panels and loose-laid carpet tile are permitted. }\end{array}$ \\
\hline & & $\begin{array}{l}\text { Ceilings: Suspended acoustical materials are selected for all general office space. Grid } \\
\text { size and spacing are based on the building planning module. Avoid inaccessible ceiling } \\
\text { systems. The recommended standard ceiling tile is a commercial quality, } 600 \mathrm{~mm} \text { by } \\
600 \mathrm{~mm} \text { regular lay-in ( } 2 \text {-foot by } 2 \text {-foot) tile. }\end{array}$ \\
\hline & & $\begin{array}{l}\text { Doors: The finish for solid core wood doors in general office spaces are limited to } \\
\text { wood veneer. Glass doors may be used at entrances to tenant suites. }\end{array}$ \\
\hline & & $\begin{array}{l}\text { Internal Corridors: Corridors within general office areas receive the same finishes as } \\
\text { the office areas themselves. Color changes may be useful in these areas for } \\
\text { orientation. }\end{array}$ \\
\hline & 2 & $\begin{array}{l}\text { Ceilings: Suspended acoustical materials are selected for all general office space. Grid } \\
\text { size and spacing should be based on the building planning module. Avoid inaccessible } \\
\text { ceiling systems. The recommended standard ceiling tile is a commercial quality, } 600 \\
\text { mm by } 600 \mathrm{~mm} \text { regular lay-in ( } 2 \text {-foot by } 2 \text {-foot) tile. }\end{array}$ \\
\hline
\end{tabular}




$\begin{array}{ll}\text { Number of } & 3 \\ \text { storey } & 2 \\ & 1 \\ \text { Age of building } & 0 \\ & 3 \\ & 2 \\ & 1 \\ & 0\end{array}$

Management Security

Cleaning services recycle policy

Computerize
Internal Corridors: Corridors within general office areas should receive the same finishes as the office areas themselves. Color changes may be useful in these areas for orientation.

Ceilings: Grid size and spacing should be based on the building planning module. Avoid inaccessible ceiling systems. The recommended standard ceiling tile is a commercial quality, $600 \mathrm{~mm}$ by $600 \mathrm{~mm}$ regular lay-in (2-foot by 2 -foot) tile.

Doors: Glass doors are used at entrances to tenant suites.

Internal Corridors: Corridors within general office areas should receive the same finishes as the office areas themselves.

Ceilings: Grid size and spacing are not based on the building planning module. Inaccessible ceiling systems.

Doors: Glass doors are used at entrances to tenant suites.

Internal Corridors: Corridors within general office areas not receive the same finishes as the office areas themselves.

Lobby design includes foyers, entries to halls, and security screening areas at or near the entrance to a building, and is meant to welcome and direct tenants and visitors, control access, and provide exit ways from buildings. This space type is often designed with both secure and non-secure areas. The lobby space type does not include elevator lobbies. Building lobbies often serve as the "public face" of building interiors. Lobby design includes entries to halls, and security screening areas at or near the entrance to a building or, and is meant to welcome and direct tenants and visitors, and provide exit ways from buildings. The lobby space type does not include elevator lobbies. Building lobbies often serve as the "public face" of building interiors.

Lobby design includes entries to halls, and security screening, and provides exit ways from buildings. The lobby space type is including elevator lobbies. Building lobbies often serve as the "public face" of building interiors.

Lobby design includes security screening, and provides exit ways from buildings. The lobby space type is including elevator lobbies. Building lobbies are not serving as the "public face" of building interiors.

High-rise (Above 30)

Mid-rise (Between 20-29)

Low-rise (Between 10-19)

None (Below 10)

Newly constructed

Fully reconstructed

Renovated \& reconstructed

Poor construction/ old building

$24 \mathrm{hr}$ access (card key), round-the-clock security, video surveillance, modern security service

Video surveillance, round-the-clock security, modern security service

Modern security service, round- the-clock security service

Round- the-clock security service

International standards/ hiring contractor/ large number of maintenance staff/ 24 hours services

Hiring contractor or run by owner/ limited number of maintenance staff/ working hour services

Generally run by owner/ limited number of maintenance staff

Poor maintenance services/ lack number of maintenance staff

International standards/ hiring contractor/ large number of maintenance staff/ 24 hours services

Hiring contractor or run by owner/ limited number of maintenance staff/ working hour services

Generally run by owner/ limited number of maintenance staff

Poor maintenance services/ lack number of maintenance staff

New federal commercial buildings must meet standards in 10 CFR 434, based on the ANSI/ASHRAE/IESNA Standard 90.1-1989.

International standards or run by owner

Generally run by owner

Poor energy saving/ recycle policy

High quality building automation system 


$\begin{array}{ll}\text { building } & 2 \\ \text { management } & 1 \\ \text { system } & 0 \\ \text { Functionality } & \\ \text { Floor size } & 3 \\ & 2 \\ & 1 \\ \text { Floor ceiling } & 0 \\ \text { height } & 2 \\ & 1 \\ \text { Space efficiency } & 3 \\ & 2 \\ & 1 \\ \text { Column layout } & 3 \\ & 2 \\ & 1 \\ & 0 \\ \text { Floor loading } & 3 \\ & 2 \\ & 1 \\ & 0\end{array}$

Services

Toilet facilities sevices

Work

environment

Direct digital controls

Electronic controls

None

Generally $>20,000$ (sqm)

Generally $>15,000$ sqm

Generally $>10,000$ (sqm)

Below 10,000 (sqm)

Generally $>3.3 \mathrm{~m}$

$3.3 \mathrm{~m}$

$<3.3 \mathrm{~m}$

$<2.75 \mathrm{~m}$

Generally $>1,000$ (sqm), largely column free

Generally $>600$ sqm largely column free

$<600$ sqm largely column free

Any size

Open, rational, and functional; distance between pillars at least $6 \mathrm{~m}$

Distance between pillars below $6 \mathrm{~m}$

"Corridor rooms" - layout is acceptable

Below standards

High density flooring floor loads/ 400 - $450 \mathrm{~kg}$ per 1sq. m/ 320 PSF

Design floor loads / 250 PSF

Design floor loads/ 50 PSF (minimum requirement)

Below standards

Floor: Typically poured-in-place, reinforced concrete slab. Toilets located within raised floor tenant office suites, a composite steel/concrete pedestal raised slab area is provided.

Ventilation: Typically a $100 \%$ direct exhaust system operated by a timer or the building automation system in order to eliminate odors and facilitate quality indoor air.

Lighting: Typically energy-efficient lighting fixtures, such as recessed fluorescent light fixtures located in the soffit above the lavatory and the toilet, combined with occupancy sensors to minimize energy consumption.

Access: Toilets are typically located in the proximity of the department, agency, or agency official for ease of access.

Floor: Toilets located within raised floor tenant office suites, a composite steel/concrete pedestal raised slab area is provided.

Ventilation: Typically a 100\% direct exhaust system operated by the building automation system.

Access: Toilets are typically located in the proximity of the department, agency, or agency official for ease of access.

Floor: Toilets located within raised floor tenant office suites.

Poor ventilation.

Access: Toilets are typically located in the proximity of the department, agency, or agency official for ease of access.

Limited toilet facilities

Electrical: dual city power supply with automatic change-over or a generator power supply system back-up. Full power for all essential services and ventilation and at least $50 \%$ power for lighting and lifts.

IT: reliable provider, fiber optics

Electrical: Full power for essential services and full ventilation.

IT: reliable telecommunications provider

Electrical: Standards

IT: at least 3 phone lines per 100 sq. $m$

Below standards

A landmark office building located in a major CBD office markets which is a pace setter in establishment rents \& includes: ample natural light \& good views/outlook.

High quality space including good views/outlook; quality

Moderate quality of work environment/ limited views

Poor quality of work environment/ lack of views 


\begin{tabular}{|c|c|c|}
\hline Heating, & 3 & 4/2-pipe systems of air-conditioning and ventilation, preferably climate control \\
\hline Ventilation \& Air & 2 & Split-system air-conditioning is acceptable \\
\hline Conditioning & 1 & Split-system air-conditioning as an option \\
\hline & 0 & Poor services of HVAC \\
\hline Ease of services & 3 & Installed or ready for installation \\
\hline upgrading \& & 2 & Installation available \\
\hline maintenance & 1 & Limited of upgrading \\
\hline & 0 & None \\
\hline Access \& circulatic & & \\
\hline Lift performance & 3 & $\begin{array}{l}\text { Waiting interval not to exceed } 25 \text { seconds, handling capacity in excess of } 15 \% \text { and a } \\
\text { high quality ride with low noise. At least one dedicated goods lift. }\end{array}$ \\
\hline & 2 & $\begin{array}{l}\text { Waiting interval not to exceed } 30 \text { second, handling capacity around } 14-15 \% \text { and a } \\
\text { good quality ride. }\end{array}$ \\
\hline & 1 & Waiting interval not to exceed 35 seconds, handling capacity around $13-14 \%$. \\
\hline & 0 & Below standards \\
\hline Lift design & 3 & $\begin{array}{l}\text { Excellent design of modern passenger and cargo lifts/ large size/ provide sprinkler/ } \\
\text { provide smoke detector to initiate lift firefighter's service and building fire alarm } \\
\text { system }\end{array}$ \\
\hline & 2 & $\begin{array}{l}\text { Moderate design of modern passenger and cargo lift/ medium size/ provide building } \\
\text { fire alarm system }\end{array}$ \\
\hline & 1 & $\begin{array}{l}\text { Poor design of modern passenger and cargo lift/ small size/ provide building fire } \\
\text { alarm system }\end{array}$ \\
\hline & 0 & Poor design of passenger and cargo lift/ small size \\
\hline Number of car & 3 & 1 car park space per 100 sq. m of premises \\
\hline park & 2 & 1 car park space per 500 sq. $\mathrm{m}$ of premises \\
\hline & 1 & Limited car park space \\
\hline & 0 & None \\
\hline park & 3 & Guarded surface, underground car park/ in building car park \\
\hline distance & 2 & Underground car park / in building car park \\
\hline building & 1 & $<50$ meter car park distance from building \\
\hline & 0 & $>50$ meter car park distance from building \\
\hline Building & 3 & Excellent quality access to/from an attractive street setting \& premium presentation \\
\hline finding & 2 & Quality access to/from an attractive street setting; quality presentation \\
\hline & 1 & Moderate quality access to/from an attractive street setting; quality presentation \\
\hline & 0 & Poor quality access to/from an attractive street setting; quality presentation \\
\hline Location & & \\
\hline Location & 3 & Determined by GIS \\
\hline commercial & 2 & \\
\hline feature & 1 & \\
\hline & 0 & \\
\hline Availability & 3 & Determined by GIS \\
\hline transport & 2 & \\
\hline options & 1 & \\
\hline & 0 & \\
\hline Transportation & 3 & Determined by GIS \\
\hline distance & 2 & \\
\hline & 1 & \\
\hline & 0 & \\
\hline Vehicle flow & 3 & Determined by GIS \\
\hline & 2 & \\
\hline & 1 & \\
\hline & 0 & \\
\hline Efficiency & 3 & Determined by GIS \\
\hline property & 2 & \\
\hline markets & 1 & \\
\hline & 0 & \\
\hline Green \& sustainab & e building & \\
\hline Indoor & 3 & Refer to Green Building Index Malaysia \\
\hline environment & 2 & \\
\hline quality & 1 & \\
\hline
\end{tabular}




\begin{tabular}{|c|c|c|}
\hline \multirow{3}{*}{$\begin{array}{l}\text { Sustainable site } \\
\text { planning }\end{array}$} & 0 & \multirow{3}{*}{ Refer to Green Building Index Malaysia } \\
\hline & 3 & \\
\hline & 2 & \\
\hline & 1 & \\
\hline & 0 & \\
\hline \multirow{4}{*}{$\begin{array}{l}\text { Material } \\
\text { resources }\end{array}$} & 3 & Refer to Green Building Index Malaysia \\
\hline & 2 & \\
\hline & 1 & \\
\hline & 0 & \\
\hline \multirow[t]{4}{*}{ Water efficiency } & 3 & Refer to Green Building Index Malaysia \\
\hline & 2 & \\
\hline & 1 & \\
\hline & 0 & \\
\hline \multirow[t]{4}{*}{ Innovation } & 3 & Refer to Green Building Index Malaysia \\
\hline & 2 & \\
\hline & 1 & \\
\hline & 0 & \\
\hline \multicolumn{3}{|l|}{ Amenities } \\
\hline \multirow[t]{4}{*}{ Landscape } & 3 & Excellent landscape/ Large landscape area \\
\hline & 2 & Moderate landscape/ Medium size of landscape area \\
\hline & 1 & Poor landscape/ Small size of landscape area \\
\hline & 0 & None \\
\hline \multirow{4}{*}{$\begin{array}{l}\text { Bank, postal, } \\
\text { other retails }\end{array}$} & 3 & Includes Bank, Postal and other retails \\
\hline & 2 & Includes Bank or Postal and other retails \\
\hline & 1 & Includes other retails \\
\hline & 0 & None \\
\hline \multirow[t]{4}{*}{ Gym, sport club } & 3 & Excellent gym and sport club \\
\hline & 2 & Moderate gym and sport club \\
\hline & 1 & Poor gym and sport club \\
\hline & 0 & None \\
\hline \multirow{4}{*}{$\begin{array}{l}\text { Restaurant } \\
\text { café }\end{array}$} & 3 & Excellent restaurants \& cafe ( 5 stars) \\
\hline & 2 & Moderate restaurants \& cafe \\
\hline & 1 & Poor restaurants \& cafe \\
\hline & 0 & None \\
\hline \multirow{4}{*}{$\begin{array}{l}\text { Pantry, prayer } \\
\text { room, children } \\
\text { nursery }\end{array}$} & 3 & Includes pantry, Prayer room and Children nursery \\
\hline & 2 & Includes Two of the elements above \\
\hline & 1 & Includes One of the elements above \\
\hline & 0 & None \\
\hline
\end{tabular}

\section{Conclusion}

As a result, based on the framework that shown in Table 1, these characteristics are formed from the entire assessment models that have been applied in Malaysian PBO. With this framework, research relates will be more efficient, effective and reliable. Since the government and private sectors have been looking deep to promote new building and locational characteristics for PBO in Malaysia, detailed elicitation of the characteristics of the PBO is essential. Our office property market will be drastically increased if the building and locational characteristics of PBO are meeting the needs of property market participants. Due to this, the special research to look on characteristics, and locational must be undertaken in order to facilitate understanding of the building and locational characteristics of PBO in Malaysia.

\section{References}

Adnan, M. Y. \& Daud, M. N. (2008). Identifying the Potential Criteria and Sub-Criteria for Classification of Office Buildings in Malaysia, International Real Estate Research Symposium 2008, Kuala Lumpur.

Bird, R. (1996). Defining Quality in New Zealand Office Developments Relative to International Standards. BOMA New Zealand, Auckland.

Darus, M. Z., Hashim, N. A., Salleh, E., Haw, L. C., Rashid, A. K. A. \& Abdul Manan, S. N. (2009). Development of Rating System For Sustainable Building In Malaysia. WSEAS Transactions on Environment and Development, 3(5). 
Duntavs, A. (2006). Colliers International Baltic Commercial. Real Estate Market Overview 2006, Gauja Hall.

Safian, E. E. M. (2010). Model klasifikasi bagi pejabat binaan khas di kawasan segi tiga emas Kuala Lumpur, UTHM, Master thesis.

Safian, E. E. M., Bagdad, M., \& Nawawi, A. H. (2011). The characteristics of purpose built offices in Malaysia: a review of issues (No. 39422). University Library of Munich, Germany.

NAPIC. (1994). National Property Information Centre. 1994 Property Market Report. Kuala Lumpur, Malaysia: Valuation and Property Services Department.

NAPIC. (2007). National Property Information Centre. 2007 Property Market Report. Kuala Lumpur, Malaysia: Valuation and Property Services Department.

NIBS. (2009). Get Energized about High Performance Building - Apr 022009.

Rahardjati, R., Khamidi, M. F. \& Idrus, A. (2010). The Level of Importance of Criteria and Sub Criteria in Green Building Index Malaysia. In: International Conference on Sustainable Building and Infrastructure (ICSBI 2010), 15-17 June 2010, Kuala Lumpur Convention Centre.

Rahim \& Co. (2009). The Klang Valley Office Market - An indication of Trends 1993-2008, Rahim \& Co., Kuala Lumpur. 